\title{
Implementasi Generalized Vector Space Model (GVSM) dalam Pencarian Buku di Perpustakaan
}

\author{
I Made Suwija Putra, Ni Putu Ayu Widiari, I Wayan Gunaya \\ Program Studi Teknologi Informasi, Fakultas Teknik, Universitas Udayana \\ Bukit Jimbaran, Bali, Indonesia, telp. (0361) 701806 \\ e-mail: putrasuwija@unud.ac.id, widiariayyu@gmail.com, gunnayaa@gmail.com
}

\begin{abstract}
Abstrak
Perpustakaan sebagai tempat koleksi buku yang besar tentu akan menemui kesulitan pelayanan pencarian buku jika masih menggunakan teknologi konvensional. Dalam ilmu Information Retrieval terdapat beberapa metode dalam pencarian dokumen yang relevan, salah satunya Generalized Vector Space Model (GVSM). Metode ini merupakan perkembangan dari Vector Space Model yang menggunakan model aljabar. GVSM menggunakan pertimbangan kedekatan antar kata yang dinyatakan dalam vector dua dimensi. Dalam Aplikasi pencarian buku, judul, pengarang, dan sinopsis buku dimasukkan ke dalam database dan dilakukan preprocessing diantaranya tokenisasi, stopword removal, dan stemming. Hal yang sama untuk kata kunci (query) pencarian yang diinputkan user juga dilakukan proses preprocessing. Dalam GVSM, dokumen dan query pencarian akan diubah kedalam bentuk vector dan dicari similaritasnya berdasarkan perkalian vector. Hasil dari implementasi metode GVSM dalam aplikasi pencarian buku di perpustakaan didapatkan hasil perbandingan nilai precision dan recall sebesar 0.703 dan 0.910 yang artinya hasil pencarian yang ditampilkan masih mendekati keinginan user.
\end{abstract}

Kata Kunci: Pencarian Dokumen, Generalized Vector Space Model, Similaritas, Query

\begin{abstract}
The library as a large collection of books will certainly encounter difficulties in book search services if they are still using conventional technology. In Information Retrieval there are several methods in finding relevant documents, one them is the Generalized Vector Space Model (GVSM). This method is a development of the Vector Space Model uses algebraic models. GVSM uses closeness between words expressed in two-dimensional vectors. In the book search application, title, author, and synopsis the book stored in the database and then preprocessing includes tokenization, stop word removal, and stemming. This preprocessing also being done for search keywords entered by the user. In GVSM, documents and search queries will be converted into vector form and look for similarity based on vector multiplication. The results of the implementation of the GVSM method in book search applications in the library showed that the comparison of precision and recall values was 0.703 and 0.910 , which meant that the search results displayed were still closer to the user's desire.
\end{abstract}

Keywords: Document Search, Generalized Vector Space Model, Similarity, Query

\section{Pendahuluan}

Buku merupakan kumpulan dari suatu informasi yang dimana informasi-informasi didalamnya saling mendukung dan memiliki satu tema yang sama[1] sehingga buku dikatakan sebagai jendela informasi dunia. Perpustakaan merupakan tempat mengkoleksi informasi atau buku yang massif saat ini sudah banyak memiliki sistem informasi perpustakaan guna mendukung pelayanan pendataan, pencarian, dan peminjaman buku[2]. Khusus untuk proses pencarian sangat diperlukan saat ini untuk menunjang dan mempermudah dalam memperoleh dokumen buku yang relevan dan sesuai dengan kebutuhan yang diinginkan.

Kebanyakan sistem pencarian dokumen buku di perpustakaan daerah maupun di instansi pemerintah masih menggunakan pencarian biasa yaitu mencocokan kata kunci yang sama dengan judul buku sesuai dengan query kondisi bahasa SQL. Hal ini terkadang menyebabkan 
hasil pencarian yang ditampilkan tidak mencerminkan keinginan user yang sesungguhnya atau keinginan user untuk mencari buku yang mengandung kata kunci yang tidak ada dalam judul buku, melainkan ada di dalam sinopsis buku. Berdasarkan hal tersebut, maka diperlukan sebuah sistem perpusatakaan yang dapat memberikan fitur pencarian lebih dalam bukan hanya sampai kepada judul buku namun juga isi buku guna menemukan informasi atau dokumen diperoleh secara cepat dan efisien. Namun saat ini mendapatkan buku yang sesuai akan sulit dikarenakan untuk mengetahui informasi yang terkandung didalam suatu buku harus membaca sinopsisnya karena judul belum bisa menggambarkan isi dari buku. Untuk memudahkan hal ini, sistem temu kembali informasi dapat diaplikasikan. Sistem temu kembali informasi dapat digunakan untuk mencari buku dengan syarat dimana tidak hanya buku dengan kueri yang sama yang ditampilkan, namun juga buku yang memiliki relevansi dengan kueri yang dimasukan. Metode yang dapat digunakan dalam information retrieval yaitu model klasik Boolean, model klasik vector, klasik probabilistik, dan model terstruktur[3]. Model klasik vector merupakan metode retrieval yang menggunakan konsep ruang vector. Pengembangan dari model ini yaitu Generalized Vector Space Model, dimana pada GVSM digunakan min-term dari kueri untuk menentukan kemungkinan frekuensi kemunculan kata.

Penelitian sebelumnya mengenai GVSM sudah dilakukan pada penelitian[4] yang dimana hasil yang didapatkan dengan menggunakan metode GVSM dapat menjalankan fungsi-fungsi pencarian dengan baik dan memiliki keakuratan yang tinggi. Penelitian lain[5] yang menggunakan metode GVSM untuk pencarian informasi pada dokumen di Teknik Elektro di UPT BPI LIPI, menghasilkan kesimpulan GVSM mampu mempermudah pencarian dokumen tertentu yang mengandung kata kunci (query) yang dimasukan oleh pengguna. Dalam peneltian ini akan diuji kembali dengan menggunakan contoh data buku dari perpustakaan yang berbeda untuk mendapatkan tingkat precision dan recall yang merupakan nilai keefektifan dari hasil uji metode GVSM.

\section{Metodologi Penelitian}

Metodologi penelitian yang dilakukan dalam penelitian ini yaitu menggunakan pendekatan kuantitatif yang menitikberatkan pada aspek numerik sebagai data, baik dalam tahap pengumpulan data maupun hasil penelitian. Berikut ini adalah diagram alir dari tahapan penelitian seperti yang ditunjukan pada Gambar 1 di bawah ini.

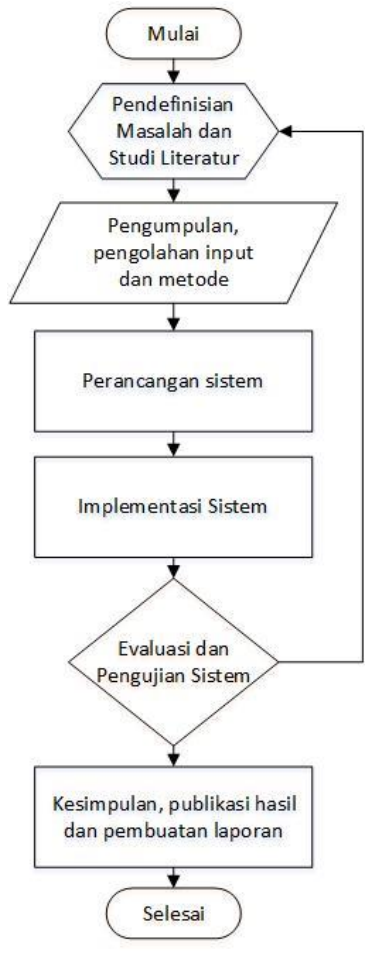

Gambar 1 Diagaram alir tahapan penelitian 
Penelitian ini dimulai dari mendefenisikan masalah yaitu mengenai bagaimana implementasi GVSM dalam aplikasi pencarian buku, yang dilanjutkan dengan studi literatur mengenai GVSM. Tahapan selanjutnya adalah mengumpulkan data, data yang digunakan pada penelitian ini berupa data buku yang dilengkapi dengan judul dan synopsis. Setelah semua perangkat terkumpul selanjutnya membuat perancangan dan implementasi sistem dan database. Setelah sistem jadi dilakukan pengujian dengan menggunakan data uji dan menarik kesimpulan dari penelitian yang terlah dilakukan.

Penelitian ini menggunakan metodologi penelitian eksperimental dimana menitikberatkan pada riset kuantitatif. Penelitian menghasilkan outcome berupa hasil pencarian buku yang berdasarkan relevansi sinopsis dengan kueri yang dimasukkan, yang selanjutnya akan dilakukan proses perhitungan nilai precision dan recall dari sistem temu kembali yang dibuat.

\section{Kajian Pustaka}

\subsection{Sistem Temu Kembali Informasi (Information Retrieval)}

Sistem temu kembali informasi atau information retrieval merupakan sistem yang proses besarnya adalah untuk menemukan informasi yang relevan terhadap kebutuhan pengguna dari suatu sumber informasi yang banyak secara otomatis[6]. Pengaplikasian dari sistem temu kembali informasi adalah search-engine atau mesin pencari. Sistem temu kembali menggunakan dokumen sebagai objek datanya yang merupakan sumber dari informasi. Dokumen akan dilakukan pengindeksan menggunakan sistem tertentu, seperti TF-IDF. Sistem temu kembali informasi yang baik mampu menampilkan dokumen-dokumen relevan yang sesuai dengan kueri yang dimasukkan, mengurutkan dokumen tersebut, dan membuang dokumen yang tidak relevan. Terdapat berbagai metode yang dapat digunakan dalam pengindeksan ataupun dalam pencarian dokumen-dokumen relevan. Sistem temu kembali juga menggunakan nilai precision dan recall sebagai pengukur efektifitas dari sistem temu kembali informasi, dimana sistem temu kembali informasi dianggap baik jika nilai precision dengan recall-nya sama (1:1).

\subsection{Text Preprocessing}

Text preprocessing merupakan tahapan awal dimana dokumen akan dilakukan proses tokenisasi dan stopword removal. Proses ini dilakukan untuk mengubah data menjadi bentuk yang lebih terstruktur. Tokenisasi adalah proses untuk membagi teks dalam kalimat, paragraf, maupun dokumen, menjadi bentuk token atau bagian tertentu. Tahapan tokenisasi diawali dengan pembersihan data dari tanda baca, tag html, dan angka yang selanjutnya tiap term yang ada diganti menjadi huruf kecil.

Stopword removal adalah proses yang digunakan untuk menghilangkan stopword list[7]. Stopword list merupakan kata-kata yang diabaikan dalam pemrosesan data. Karakteristik dari stopword yaitu frekuensi kemunculnya tinggi dan berupa kata ganti orang atau kata penghubung. Dalam stopword list, tidak ada list yang pasti dan benar untuk stopword. Tujuan dari penghilangan stopword ini adalah untuk mengurangi jumlah kata dalam sebuah dokumen yang akan berpengaruh dalam kecepatan dan performa pemrosesan.

\subsection{Porter Stemming}

Stemming merupakan proses membentuk kata dasar dari kata atau kumpulan kata yang sudah diberikan awalan dan akhiran. Stemming menggunakan struktur morfologi Bahasa untuk mengubah kata berimbuhan menjadi kata dasarnya[8]. Proses stemming digunakan dalam proses pencarian informasi untuk meningkatkan informasi yang didapatkan lebih berkualitas. Artinya hubungan kata dengan dengan varian kata lainnya didapatkan. Sebagai contoh kata "diculik", "menculik" (melakukan tindakan culik) dan "penculik" (orang yang menculik) dengan masing-masing imbuhan tersebut memiliki arti yang berbeda-beda, dengan proses stemming didapatkanlah hasil sebuah kata "culik" sehingga arti dan varian kata di atas saling berhubungan.

Proses stemming untuk corpus yang menggunakan Bahasa Indonesia berbeda dengan corpus yang menggunakan Bahasa asing atau Inggris. Pada teks berbahasa Inggris, proses yang diperlukan hanya proses menghilangkan sufiks (akhiran). Sedangkan pada teks berbahasa Indonesia, selain sufiks, prefiks, dan konfiks juga dihilangkan. Stemming pada Bahasa Indonesia didasarkan pada basis aturan (rule based), yang artinya akan melakukan pemotongan imbuhan dengan mematuhi aturan-aturan penggunaan suatu imbuhan. Stemming ini akan memeriksa setiap kata yang memiliki suatu imbuhan (sufiks ataupun prefiks) sampai benar-benar tidak 
ditemukan imbuhan pada kata tersebut. Contoh algoritma stemming berbasiskan aturan adalah Stemmer Porter[9].

\subsection{Generalized Vector Space Model}

Generalized Vector Space Model (GVSM) merupakan metode yang dikembangkan dari metode sebelumnya yaitu Vector Space Model dengan mempertimbangkan kesamaan arti antar kata atau term dengan lebih akurat dalam mewakili representasi dari dokumen[10]. Wong, et al. (1985) memprakarsai Generalized Vector Space Model (GVSM) dengan memperkenalkan korelasi antar term, di mana vektor index term dianggap independen secara linier tetapi tidak dianggap berpasangan orthogonal. Vektor index term terdiri dari komponen-komponen yang lebih kecil[11][12]. Tahapan dari GVSM adalah sebagai berikut.

a. Menentukan minterm dari query untuk menentukan kemungkinan frekuensi munculnya kata. Panjang minterm ini didasarkan pada banyak kata yang dimasukan pada query.

b. Minterm kemudian diubah menjadi vektor orthogonal $\overrightarrow{m_{l}}$ sesuai dengan polanya, sehingga dapat didefinisikan sebuah set vektor $\overrightarrow{m_{\imath}}$ yaitu $\overrightarrow{m_{1}}=(1,0, \ldots, 0,0), \overrightarrow{m_{2}}=(0,1, \ldots, 0,0)$, hingga $\overrightarrow{m_{2} t}=(0,0, \ldots, 0,1)$.

c. Menghitung index term dengan persamaan

$$
\overrightarrow{k_{l}}=\frac{\sum_{\forall r, g_{i}\left(m_{r}\right)=1} c_{i, r} \overrightarrow{m_{r}}}{\sqrt{\sum_{\forall r, g_{i}}\left(m_{r}\right)=1} c_{i, r}}
$$

d. Dokumen (d) dan query (q) kemudian diubah menjadi vector dengan persamaan

$$
\begin{aligned}
\overrightarrow{d_{j}} & =\sum_{i=1}^{n} w_{i j} \times \overrightarrow{k_{i}} \\
\vec{q} & =\sum_{i=1}^{n} q_{i} \times \overrightarrow{k_{i}}
\end{aligned}
$$

e. Dokumen yang telah diubah menjadi vector kemudian diurutkan berdasarkan similaritas dengan menggunakan persamaan sebagai berikut

$$
\operatorname{sim}(\overrightarrow{d j}, \vec{q})=\frac{\overrightarrow{d j} \bullet \vec{q}}{|\overrightarrow{d j}||\vec{q}|}
$$

Perbedaan antara VSM dengan GVSM terletak pada perhitungan kolerasi antara dokumen dengan kueri. GVSM menjadikan seluruh term sebagai vector orthogonal untuk menghitung index term dan kemudian setiap term pada dokumen diubah dengan cara generalizedisasi menjadi vektor ortogonal dengan mengalikan hasil Index term dengan term dokumen dan query. Selanjutnya, masing-masing vektor dilakukan operasi perkalian titik, kemudian hasilnya akan menentukan relevansi query terhadap kumpulan dokumen.

\section{Percobaan dan Hasil}

Perancangan sistem pencarian buku dengan metode Generalized Vector Space Model (GVSM) digambarkan dengan flowchart (diagram alir). Adapun perancangan sistem dari sistem pencarian buku dengan metode GVSM ditunjukkan pada Gambar 2 di bawah ini. 


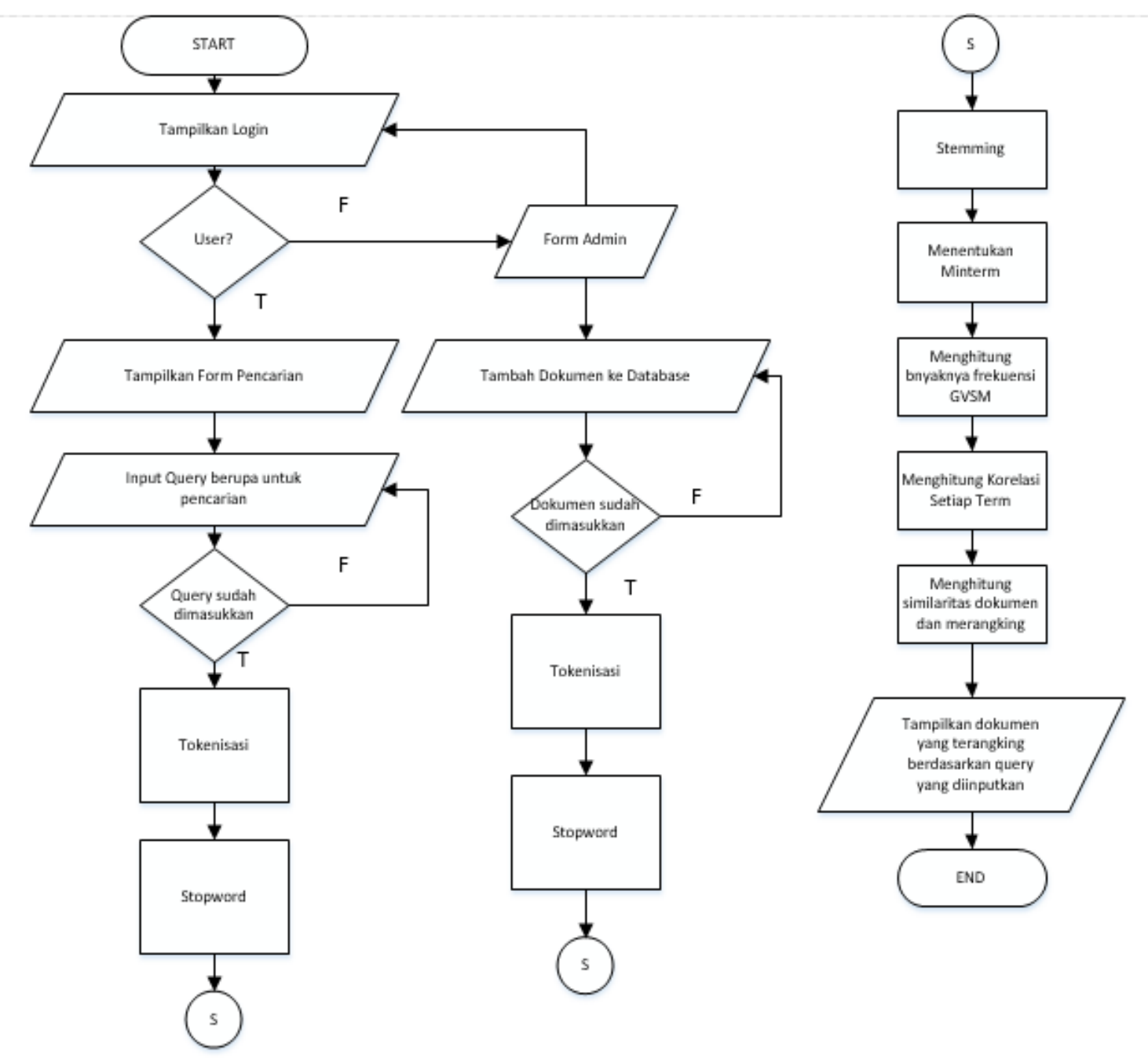

Gambar 2 Flowchart Sistem Pencarian Buku

Gambar 2 merupakan diagram alir dari sistem pencarian buku perpustakaan dengan metode GVSM (Generalized Vector Space Model). Tahap pertama dari sistem pencarian buku ini adalah menampilkan form login untuk menentukan apakah dia termasuk admin dan user. Halaman admin berisikan halaman untuk tambah abstrak buku, dimana abstrak buku akan dibersihkan dengan proses preprocessing. Halaman user berisikan form pencarian untuk memasukkan query pencarian. Query pencarian akan mengalami proses preprocessing seperti halnya dokumen. Parse query adalah tahapan preprocessing yang merubah kalimat query ke dalam kelompok kata (term). Hal ini melalui beberapa tahapan proses yaitu.

1. Tokenisasi

Tokenisasi merupakan suatu tahapan yang memperoses teks input yang berisikan beberapa kalimat dibagi menjadi unit-unit kecil yang disebut token, yang dapat berupa kata, angka atau suatu tanda baca. Dalam sistem ini tahapan tokenisasi terdiri dari karakter dari a sampai z, segala simbol dihilangkan, pemecahan-pemecahan kalimat menjadi token dilakukan berdasarkan pada spasi di dalam kalimat tersebut dan hal ini dilakukan secara otomatis. 


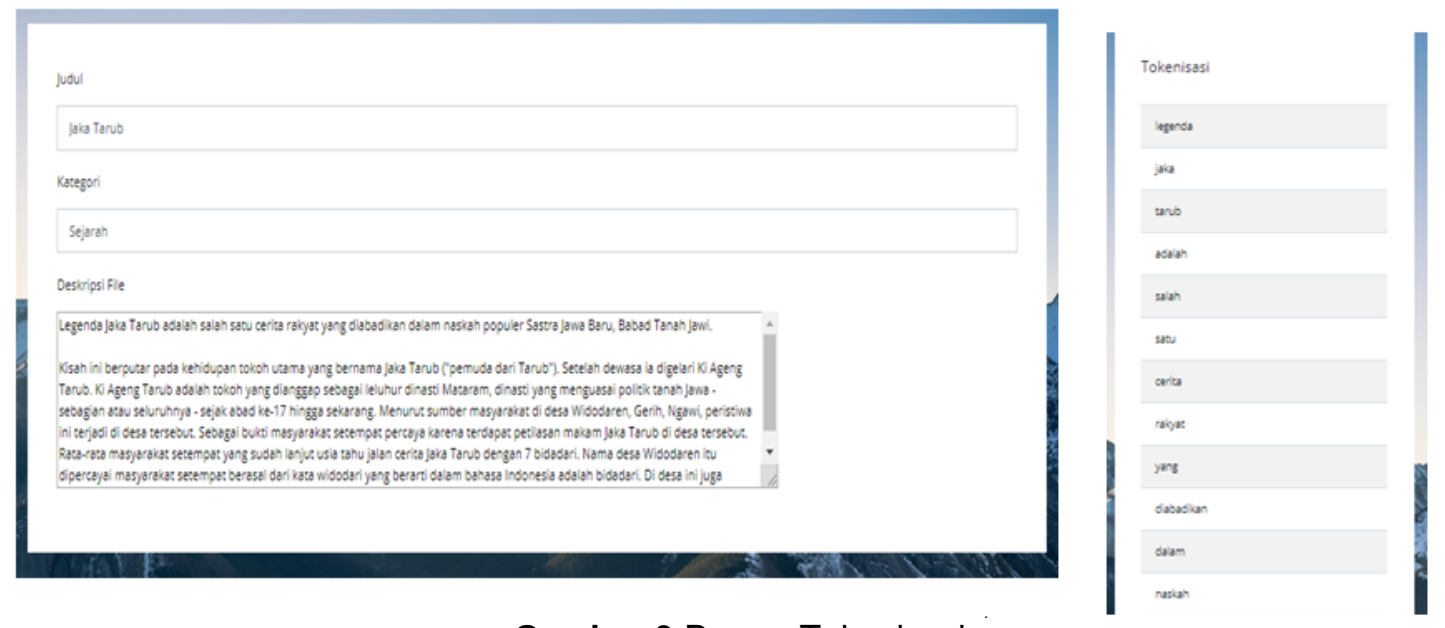

Gambar 3 Proses Tokenisasi

\section{Proses Stopword Removal}

Beberapa token atau kata yang dihasilkan dari proses proses parse dipilih dan dibuang katakata mana yang termasuk ke dalam kategori stop word dalam Bahasa Indonesia.

\section{Proses Stemming}

Setelah proses filtering pada stop word filtration maka token-token query yang dihasilkan akan dirubah ke bentuk dasarnya menjadi stemmed term query. Sistem akan membandingkan Stemmed term query yang dihasilkan tersebut dengan koleksi dokumen sehingga mengembalikan dokumen-dokumen yang relevan. Setelah proses parse query dilakukan tahapan selanjutnya adalah memodelkan query dengan kumpulan term menggunakan salah satu metode dari information retrieval. Metode yang digunakan pada penelitian ini adalah Generalized Vector Space model. Cara kerjanya adalah untuk masing-masing term atau kata yang ditemukan pada corpus dan query yang sudah melalui proses tokenisasi dan stop word removal diberi bobot dan disimpan sebagai salah satu elemen vektor untuk nantinya dihitung nilai kemiripan antara query dan dokumen dengan menggunakan operasi perkalian vektor. Setelah itu perankingan dokumen dapat dilakukan berdasarkan kemiripan antara query dan dokumen. Semakin tinggi nilai kemiripan maka dokumen tersebut yang akan dimunculkan pada peringkat teratas.

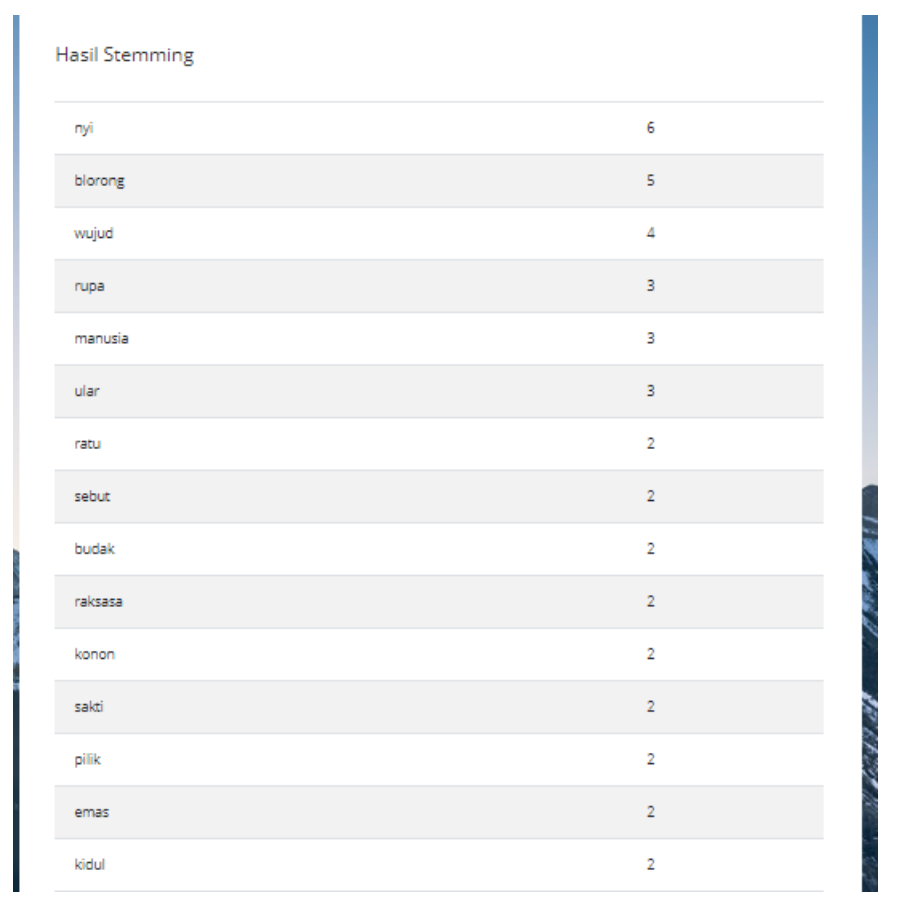


Gambar 4 Hasil Stopword Removal, Stemming, dan Penghitungan term pada dokumen

Gambar 4 merupakan gambaran hasil sebuah corpus sudah melalui proses stopword removal, stemming, dan penghitungan term pada dokumen. Pada proses stemming didapatkan term kata dasar pada dokumen yang diinputkan. Term tersebut dihitung jumlah frekuensi kemunculannya dan setiap hasil term yang didapatkan semua dimasukkan pada database yang sudah dibuat sebelumnya.

\subsection{Implementasi Sistem}

Perancangan yang telah dilakukan kemudian dimplementasikan sesaui dengan desain dilekatkan pada sistem di perpustakaan. Hasil implementasi kemudian diuji cobakan guna memastikan output yang dikeluarkan oleh aplikasi pencarian buku dengan metode GVSM (Generalized Vector Space Model) dengan inputan query dan output berupa data buku yang terkait dengan query yang diinputkan sudah sesuai.

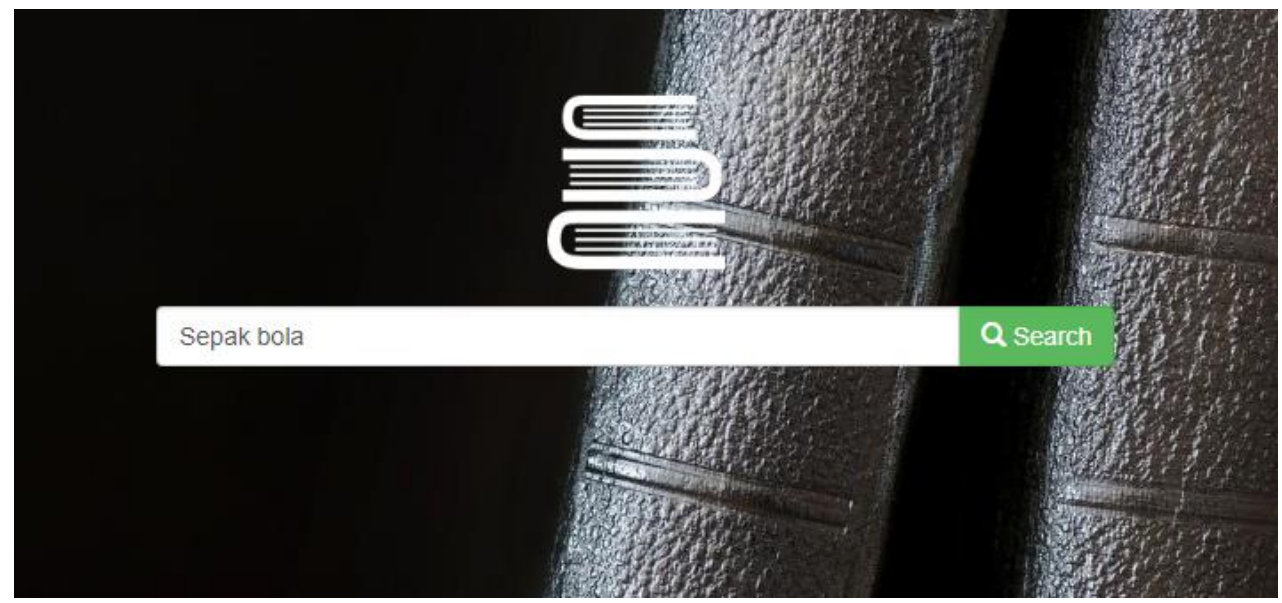

Gambar 5 Tampilan Interface Search

Gambar 5 merupakan tampilan search pada aplikasi pencarian buku dengan metode Generalized Vector Space Model (GVSM). Query yang diinputkan adalah kata kunci "sepak bola".

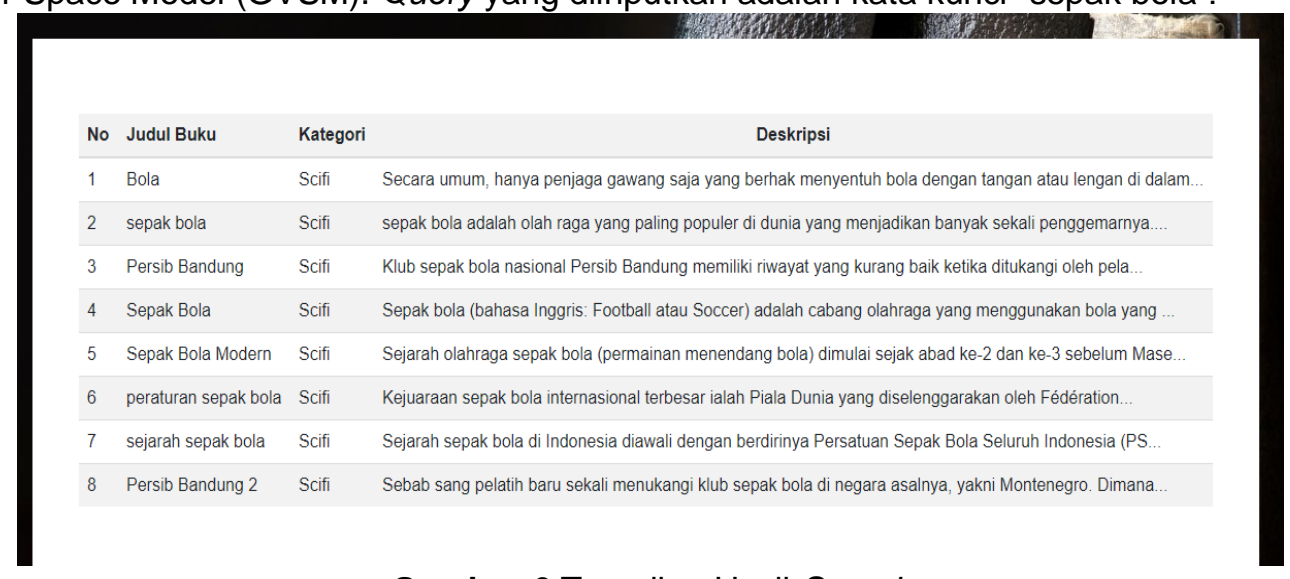

Gambar 6 Tampilan Hasil Search

Gambar 6 merupakan tampilan hasil search dari uji coba pencarian buku dengan metode GVSM (Generalized Vector Space Model). Hasil search dari query yang diinputkan adalah dimunculkan daftar dokumen buku yang judul, deskripsi yang memiliki tingkat kedekatan dengan query yang diinputkan yaitu Sepak Bola sebanyak 8 dokumen.

\subsection{Hasil Pengujian}


Untuk menguji ketepatan dan keakuratan implementasi metode GVSM dalam sistem pencarian buku diperpustakaan, dilakukan penghitungan nilai precision dan recall untuk setiap pencarian yang dilakukan user. Precision mengindikasikan tingkat kesesuaian antara informasi yang diminta oleh pengguna dengan jawaban yang diberikan oleh sistem, tetapi tidak memandang total jumlah dokumen yang relevan dalam kumpulan dokumen. Dengan kata lain nilai precision $(\mathrm{P})$ didapatkan dengan membandingkan jumlah dokumen yang relevan bagi user dengan total jumlah dokumen yang ditemukan. Sedangkan recall adalah tingkat keberhasilan sistem menemukan kembali semua dokumen yang sesuai. Nilai recall $(R)$ diperoleh rasio jumlah dokumen yang relevan bagi user dengan total jumlah dokumen dalam kumpulan dokumen yang dianggap relevan [13].

$$
\begin{aligned}
& \text { Precision }=\frac{|[a] \cap[b]|}{|[b]|} \\
& \text { Recall }=\frac{|[a] \cap[b]|}{|[a]|}
\end{aligned}
$$

Diketahui:

a : jumlah dokumen relevan

b : : jumlah dokumen yang ada dalam database

Hasil pengujian nilai precision di-retrieve oleh sistem yang telah dilakukan dengan menggunakan 10 kata kunci dan penilaian dokumen buku yang dimunculkan sistem bernilai relevan atau tidak didasarkan dari penilaian yang diberikan oleh user dalam hal ini adalah mahasiswa. Berikut ini nilai masing-masing kata kunci untuk precision dilihat dalam Tabel $1 \mathrm{di}$ bawah ini.

Tabel 1 Tabel nilai precision pada sistem pencarian buku dengan metode GVSM

\begin{tabular}{clccc}
\hline No & \multicolumn{1}{c}{ Query } & $\begin{array}{c}\text { Relevant items } \\
\text { retrieved }\end{array}$ & $\begin{array}{c}\text { Total relevant } \\
\text { items retrieved }\end{array}$ & $\mathrm{P}$ \\
\hline 1 & Harry Potter & 7 & 12 & 0.58 \\
2 & Olaharga Sepak Bola & 8 & 8 & 1 \\
3 & Tubuh Manusia & 6 & 15 & 0.4 \\
4 & Nyi Roro Kidul & 3 & 4 & 0.75 \\
5 & Bencana Tsunami & 5 & 5 & 1 \\
6 & Anatomi Manusia & 6 & 13 & 0.46 \\
7 & Hantu roh & 9 & 12 & 0.75 \\
8 & Kisah Mahabharata & 8 & 12 & 0.67 \\
9 & Laskar Pelangi & 1 & 1 & 1 \\
10 & Cinta Remaja & 3 & 0.42 \\
\hline \multicolumn{5}{c}{ Rata-rata nilai Precision }
\end{tabular}

Hasil pengujian nilai recall di-retrieve oleh sistem yang telah dilakukan dengan menggunakan 10 kata kunci dan penilaian dokumen buku yang relevan diambil dari nilai "relevant items retrieved" yang ada pada Tabel 1 . Hasil nilai recall seluruh kata kunci dapat dilihat dalam tabel 2 di bawah ini.

Tabel 2 Tabel nilai recall pada sistem pencarian buku dengan metode GVSM

\begin{tabular}{clccc}
\hline No & Query & $\begin{array}{c}\text { Relevant items } \\
\text { retrieved }\end{array}$ & $\begin{array}{c}\text { Total relevant } \\
\text { items in } \\
\text { database }\end{array}$ & $\mathrm{R}$ \\
\hline 1 & Harry Potter & 7 & 7 & 1 \\
2 & Olaharga Sepak Bola & 8 & 8 & 1 \\
3 & Tubuh Manusia & 6 & 10 & 0.6 \\
4 & Nyi Roro Kidul & 3 & 4 & 0.75 \\
5 & Bencana Tsunami & 5 & 5 & 1
\end{tabular}




\begin{tabular}{cllcc}
6 & Anatomi Manusia & 6 & 8 & 0.75 \\
7 & Hantu roh & 9 & 9 & 1 \\
8 & Kisah Mahabharata & 8 & 8 & 1 \\
9 & Laskar Pelangi & 1 & 1 & 1 \\
10 & Cinta Remaja & 3 & 3 & 1 \\
\hline & & & 0.910 \\
\hline
\end{tabular}

Hasil Pengujian nilai Precision dan Recall terlihat pada tabel 4.1 dan tabel 4.2 bahwa rata-rata hasil pengujian precision dan recall pada sistem pencarian buku dengan metode GVSM adalah 0.703 dan 0.910. Dalam bentuk perbandingan nilai precision dan nilai recall dari sistem pencarian buku dengan metode GVSM adalah 7:9.

\section{Kesimpulan}

Metode Generalized Vector Space Model adalah metode turunan dari Vector Space Model. Tahapan dari sistem pencarian dengan metode Generalized Vector Space Model adalah proses tokenisasi, stopwords removal, stemming, dilanjutkan dengan proses menentukan korelasi antar term dengan metode GVSM dengan merubah seluruh term menjadi vector orthogonal, dan hasilnya diurutkan berdasarkan tingginya similaritas dokumen. Hasil uji coba pada sistem pencarian buku dengan metode Generalized Vector Space Model ini menghasilkan nilai precision yang lebih rendah dari nilai recall dengan perbandingan 7:9. Hasil uji coba ini membuktikan bahwa sistem pencarian dengan metode GVSM ini masih efektif digunakan untuk pencarian buku di pepustakaan walaupun belum sempurna untuk dijadikan pengembangan metode sistem pencarian kedepannya.

\section{Daftar Pustaka}

[1] Pusat Bahasa Kemdikbud, "Kamus Besar Bahasa Indonesia ( KBBI )," Kementerian Pendidikan dan Budaya, 2016. .

[2] A. Firman, H. Wowor, and X. Najoan, "Sistem Informasi Perpustakaan Online Berbasis Web," E-journal Tek. Elektro dan Komput., 2016.

[3] C. D. Manning, P. Raghavan, and H. Schutze, Introduction to Information Retrieval. 2008.

[4] M. A. P. Slamet Handoko, Idhawati Hestiningsih, Achmat Ainul Afif, "Implementasi Metode Generalized Vector Space Model Pada Aplikasi Information Retrieval," J. Inform., vol. 6, no. 1, pp. 599-611, 2012.

[5] L. Robinson, "Implementasi Metode Generalized Vector Space Model Pada Aplikasi Information Retrieval untuk Pencarian Informasi Pada Kumpulan Dokumen Teknik Elektro Di UPT BPI LIPI," J. Ilm. Komput. dan Inform. ( KOMPUTA ), 2014.

[6] R. Baeza-Yates and B. Ribeiro-Neto, Modern Information Retrieval. 1999.

[7] N. K. Widyasanti, I. K. Gede, D. Putra, N. Kadek, and D. Rusjayanthi, "Seleksi Fitur Bobot Kata dengan Metode TFIDF untuk Ringkasan Bahasa Indonesia," Merpati, vol. 6, no. 2, pp. 119-126, 2018.

[8] J. Asian, H. E. Williams, and S. M. M. Tahaghoghi, "Stemming Indonesian," in Conferences in Research and Practice in Information Technology Series, 2005.

[9] P. Bagus, S. Wiguna, and B. S. Hantono, "Peningkatan Algoritma Porter Stemmer Bahasa Indonesia berdasarkan Metode Morfologi dengan Mengaplikasikan 2 Tingkat Morfologi dan Aturan Kombinasi Awalan dan Akhiran," vol. 2, no. 2, pp. 1-6, 2013.

[10] J. Singh and S. Dwivedi, "Analysis of Vector Space Model in Information Retrieval," IJCA Proceedings on National Conference on Communication Technologies \& its impact on Next Generation Computing 2012. pp. 14-18, 2012.

[11] J. Pardede, "Implementasi Multithreading untuk Meningkatkan Kinerja Information Retrieval dengan Metode GVSM." 2014.

[12] M. Abual-Rub, R. Abdullah, and N. Rashid, "A Modified Vector Space Model for Protein Retrieval," Int. J. Comput. Sci. Netw. Secur., vol. 7, no. 9, pp. 85-89, 2007.

[13] W. Hardi, "Mengukur Kinerja Search Engine: Sebuah Eksperimentasi Penilaian Precision And Recall Untuk Informasi IImiah Bidang IImu Perpustakaan Dan Informasi," Visi Pustaka [National Libr. Indones., p. 7, 2008. 